\title{
Determinants of deranged thyroid function parameters in children admitted for management of diabetic ketoacidosis/ diabetic ketosis
}

\author{
Peng Shao ${ }^{1,2}$, Shujuan Guo ${ }^{1,2}$, Guimei Li ${ }^{*}$ (D), Daogang Qin², Sen Li ${ }^{3}$ and Ying Luan²
}

\begin{abstract}
Background: Euthyroid sick syndrome (ESS) frequently arises in children admitted with diabetic ketoacidosis/ diabetic ketosis (DKA/DK). This study evaluates the interplay of various metabolic factors with occurrence of deranged thyroid function tests in children suffering from DKA/DK.

Methods: 98 DKA and 96 DK pediatric patients were selected from hospital records. Those on thyroxine replacement, with overt hypothyroidism, or with positive anti-thyroperoxidase (TPO) antibody were excluded. Tests for liver function, renal function, lipid profile, serum osmolarity, thyroid function, c-peptide levels, and glycosylated hemoglobin were done on all patients. Children were divided into euthyroid $(n=88)$ and ESS groups $(n=106)$.

Results: The ESS group had a higher level of white blood cell count (WBC), plasma glucose (PG), betahydroxybutyric acid ( $\beta-H B)$, triglyceride $(T G)$, anion gap $(A G)$, glycosylated hemoglobin $(\mathrm{HbA1C})$ and a lower level of $\mathrm{HCO}_{3}{ }^{-}$, prealbumin $(\mathrm{PA})$, and albumin (ALB) compared with the euthyroid group $(P<0.05)$. Free T3 (FT3) levels were significantly correlated to $\beta-\mathrm{HB}, \mathrm{HCO}_{3}{ }^{-}, \mathrm{AG}, \mathrm{PA}$, and $\mathrm{HbA} 1 \mathrm{c}(\mathrm{r}=-0.642,0.681,-0.377,0.581,-0.309$, respectively; $P<0.01)$. Free T4 (FT4) levels were significantly correlated to $\beta-\mathrm{HB}_{1} \mathrm{HCO}_{3}{ }^{-}$, and ALB levels $(r=-0.489,0.338,0.529$, respectively; $P<0.01)$. TSH levels were significantly affected by $\mathrm{HCO}_{3}{ }^{-}$only $(r=-0.28 ; \mathrm{P}<0.01)$. $\mathrm{HCO}_{3}{ }^{-}$level was the most important factor deciding euthyroid or ESS on logistic regression analysis $(\mathrm{OR}=0.844, P=0.004,95 \% \mathrm{Cl}=$ 0.751-0.948).
\end{abstract}

Conclusions: Lower levels of free thyroid hormones and occurrence of ESS were associated with a higher degree of acidosis in children with DKA/DK.

Keywords: Diabetes, Thyroid function, Metabolic changes, Type 1 diabetes, Children

\section{Background}

Type 1 diabetes (T1DM) is a common autoimmune disorder associated with other autoimmune diseases such as coeliac disease and autoimmune hypothyroidism.

* Correspondence: Igmusa2015@163.com

'Department of Pediatrics, Shandong Provincial Hospital, Cheeloo College of Medicine, Shandong University, Jinan 250021, Shandong, China

Full list of author information is available at the end of the article
Although no age group is exempt, children under 18 are most affected.

In children with T1DM due to insulin deficiency, blood ketone levels are higher than normal. Very high ketone levels can trigger a life-threatening condition named diabetic ketoacidosis (DKA), which is manifested by nausea, vomiting, stomach pain, breathing trouble, and loss of consciousness [1, 2]. Infection, stress, inappropriate diet/malnutrition, or medications can all

(c) The Author(s). 2020 Open Access This article is licensed under a Creative Commons Attribution 4.0 International License, which permits use, sharing, adaptation, distribution and reproduction in any medium or format, as long as you give appropriate credit to the original author(s) and the source, provide a link to the Creative Commons licence, and indicate if changes were made. The images or other third party material in this article are included in the article's Creative Commons licence, unless indicated otherwise in a credit line to the material. If material is not included in the article's Creative Commons licence and your intended use is not permitted by statutory regulation or exceeds the permitted use, you will need to obtain permission directly from the copyright holder. To view a copy of this licence, visit http://creativecommons.org/licenses/by/4.0/ The Creative Commons Public Domain Dedication waiver (http://creativecommons.org/publicdomain/zero/1.0/) applies to the data made available in this article, unless otherwise stated in a credit line to the data. 
exacerbate DKA, and it has a higher incidence in younger children [3].

Euthyroid sick syndrome (ESS), also known as nonthyroidal illness syndrome, is a transient derangement in thyroid function tests characterized by low T3 levels. ESS is reportedly associated with a higher risk of fatality among critically ill patients admitted with myocardial infarction, sepsis, trauma, and chronic kidney disease [47]. In addition, ICU patients with ESS tend to experience more severe symptoms compared to those with normal thyroid function [8]. Thyroid dysfunction occurs more often in diabetic patients relative to the general population while poor glycemic control coincides with a lower level of free T3 (FT3) in serum [9]. ESS in children with T1DM results in poor metabolic control and ketoacidosis $[10,11]$. The potential mechanisms include (but are not limited to) deranged regulation of the hypothalamicpituitary-thyroid axis, inflammatory cytokines effects, and oxidative stress effects [12].

A study reported by $\mathrm{Hu}$ et al. revealed a higher level of $\mathrm{HbA1c}$, anion gap, and plasma glucose as well as a lower level of bicarbonate in T1DM children diagnosed with DKA and ESS compared with those without ESS [13]. However, they analyzed the association of just a few of parameters to ESS in DKA. Therefore, the relationship of DKA, ESS, and various metabolic parameters like hyperglycemia, hyperketosis, acidosis, and other acute phase reactants remains to be elucidated.

In this study, we evaluated metabolic parameters such as leukocyte count, blood biochemistry, liver function, kidney function, blood lipids, and C-peptide levels in relation to risk of ESS among children with T1DM admitted for management of DKA, diabetic ketoacidosis (DK), or acute hyperglycemia.

\section{Methods}

\section{Patient recruitment and exclusion criteria}

This was a retrospective case-control study undertaken in the Pediatric Department of Shandong Provincial Hospital affiliated to Shandong University in Shandong, China. We enrolled children with newly diagnosed (or already suffering from) T1DM admitted to the hospital for management of DKA or acute hyperglycemia between January 2014 and August 2019. Ethical approval was obtained from the Ethical Committee of Shandong Provincial Hospital. Study participants and parents of minors provided signed informed consent when they were admitted to the hospital.

T1DM was diagnosed based on the American Diabetes Association criteria and International Society for Pediatric and Adolescent Diabetes (ISPAD) Clinical Practice Consensus Guidelines 2018 [14, 15]. The criteria for diagnosing DKA was blood glucose $(\mathrm{BG})>11$ $\mathrm{mmol} / \mathrm{L}$, venous $\mathrm{pH}<7.3$, or bicarbonate $<15 \mathrm{mmol} / \mathrm{L}$.
A diagnosis of DK was made if blood glucose was more than $11 \mathrm{mmol} / \mathrm{L}$, urine ketones were positive, but venous $\mathrm{pH} \geq 7.3$ or serum bicarbonate level was normal $(\geq 15$ $\mathrm{mmol} / \mathrm{L}$ ) [16]. Euthyroidism was defined when levels of thyroid function tests were within the following reference ranges: FT3 3.1-6.8 pmol/L, FT4 $12-22 \mathrm{pmol} / \mathrm{L}$, and TSH $0.27-4.2 \mu \mathrm{IU} / \mathrm{mL}$. ESS was defined when FT3 and/or FT4 levels were decreased and TSH levels were normal or decreased [13, 17, 18].

A total of 237 pediatric patients were screened. All children under the age of 18 years admitted for management of DKA/DK (either newly diagnosed or already on insulin) were included in the trial. Children with overt hypothyroidism, on thyroid medications, or those with other types of diabetes like pancreatic diabetes or juvenile type 2 diabetes, morbid obesity, or on antihyperglycemic agents other than insulin were excluded from the trial. Children on steroids or any such medication that could significantly affect thyroid function tests were also excluded from the analyses. Children with other critical organ illnesses as rheumatic heart disease, heart failure, nephrotic syndrome, coeliac disease, or chronic kidney disease as well as those positive for antiTPO antibody were also excluded.

A total of 194 children qualified for the final analysis: 88 cases in the euthyroid group including 19 cases of DKA and 69 cases of DK, and 106 in the ESS group including 79 cases of DKA and 27 cases of DK.

\section{Laboratory assays}

All samples for laboratory analysis were taken before commencing initial therapy. Serum biochemical analysis including electrolytes, renal function tests, lipid profile, and liver function tests were measured using an automatic biochemistry analyzer (AU5400, Beckman Coulter, Tokyo, Japan). Glycosylated hemoglobin (HbA1c) was measured by high-performance liquid chromatography (HLC-723G7, Tosoh Corporation, Tokyo, Japan). Thyroid function tests were measured using an automated chemi-luminescent immunoassay system (Advia Centaur, Siemens, Munich, Germany). The intra-assay and inter-assay coefficients of variation were $<6 \%$ for all parameters. Serum C-peptide (C-p) level was measured by chemi-luminescent immunometric assay (Cobas E170, Roche Diagnostics, Mannheim, Germany). Corrected $\mathrm{Na}^{+}$was derived from this formula: [(Glucose $(\mathrm{mmol} / \mathrm{L})$ $-5.6] \times 0.36+$ Serum $\left.\mathrm{Na}^{+}[19]\right]$.

\section{Statistical methods}

Normally distributed data is represented as mean \pm standard deviation (SD). Non parametric and skewed data is represented as median (interquartile range). Chisquared test was used to compare rates and proportions. Two-tailed student $\mathrm{t}$-tests was used to compare normally 
distributed data between two groups and Mann-Whitney Rank sum test was used to compare non parametric skewed data between the two groups. Pearson and Spearman correlation tests were applied to evaluate associations of parametric and nonparametric data, respectively. Multiple linear regression analysis was done to detect variables which had an independent effect on thyroid function tests. Logistic regression analysis was done using thyroid function status as a binary variable to determine which factors independently influenced the placement of a subject in a particular group. All analysis was performed on Statistical Package for Social Sciences version 25.0 (SPSS Inc. Chicago, IL, USA). A $p$-value < 0.05 was considered statistically significant.

\section{Results}

Baseline clinical and laboratory characteristics

The baseline demographic and clinical characteristics of enrolled children are shown in Table 1 . There was no statistically significant difference in mean age, gender ratio, and BMI between the euthyroid and ESS groups. White blood cell count (WBC), plasma glucose (PG), beta-hydroxybutyric acid ( $\beta$-HB), triglyceride (TG), anion gap (AG), and glycosylated hemoglobin (HbA1c) levels were significantly higher in the ESS group than in the euthyroid group, whereas serum $\mathrm{HCO}_{3}{ }^{-}$, albumin (ALB), and prealbumin (PA) levels were significantly lower in the ESS group than in the euthyroid group $(p<$ 0.05).

Table 1 Baseline clinical and laboratory characteristics in DKA/DK children

\begin{tabular}{|c|c|c|c|c|}
\hline \multirow[t]{2}{*}{ Variables } & \multicolumn{2}{|l|}{ Thyroid function } & \multirow[t]{2}{*}{$Z / T / X^{2}$} & \multirow[t]{2}{*}{$P$} \\
\hline & Euthyroidism & ESS & & \\
\hline Gender (male/female) & $50 / 38$ & $59 / 47$ & 0.03 & 0.871 \\
\hline Age (years) & $7.16 \pm 4.24$ & $7.42 \pm 4.27$ & 0.416 & 0.678 \\
\hline $\mathrm{BMI}\left(\mathrm{kg} / \mathrm{m}^{2}\right)$ & $16.93 \pm 3.19$ & $15.80 \pm 3.07$ & -1.589 & 0.116 \\
\hline WBC $\left(\times 10^{9} / \mathrm{L}\right)$ & $7.25(6.15 \sim 9.82)$ & $10.72(7.82 \sim 16.9)$ & -5.316 & $<0.001^{*}$ \\
\hline PG (mmol/L) & $19.13(14.97 \sim 27.8)$ & $21.77(16.89 \sim 29.46)$ & -3.222 & $0.001^{*}$ \\
\hline BUN (mmol/L) & $5.35(4.48 \sim 6.35)$ & $4.95(3.93 \sim 6.75)$ & -0.372 & 0.71 \\
\hline $\mathrm{Cr}(\mathrm{umol} / \mathrm{L})$ & $31.3(23.55 \sim 48.63)$ & $34.05(25.15 \sim 45.64)$ & -0.765 & 0.444 \\
\hline$\beta-\mathrm{HB}(\mathrm{mmol} / \mathrm{L})$ & $2.92(1.61 \sim 5.22)$ & $6.52(4.28 \sim 8.46)$ & -7.375 & $<0.001^{*}$ \\
\hline $\mathrm{K}^{+}(\mathrm{mmol} / \mathrm{L})$ & $4.25(3.8 \sim 4.6)$ & $4.2(3.5 \sim 4.63)$ & -1.403 & 0.161 \\
\hline $\mathrm{Na}^{+}(\mathrm{mmol} / \mathrm{L})$ & $133.42 \pm 4.72$ & $131.02 \pm 5.28$ & 3.309 & $0.001^{*}$ \\
\hline Corrected $\mathrm{Na}^{+}(\mathrm{mmol} / \mathrm{L})$ & $139(137.2 \sim 141.7)$ & $138.6(134 \sim 140.6)$ & -1.405 & 0.16 \\
\hline $\mathrm{Cl}^{-}(\mathrm{mmol} / \mathrm{L})$ & $99.3(96 \sim 103)$ & $101(96 \sim 106.15)$ & -1.256 & 0.209 \\
\hline $\mathrm{HCO}_{3}^{-}(\mathrm{mmol} / \mathrm{L})$ & $19.15(16.4 \sim 21.9)$ & $9.55(6.63 \sim 14.75)$ & -7.946 & $<0.001^{*}$ \\
\hline OSM (mOsm/L) & $284.39(279 \sim 289.03)$ & $280.02(272.05 \sim 286.49)$ & -0.978 & 0.328 \\
\hline $\mathrm{AG}(\mathrm{mmol} / \mathrm{L})$ & $19.2(17.2 \sim 22.15)$ & $22.97(19.65 \sim 27.53)$ & -4.857 & $<0.001^{*}$ \\
\hline $\mathrm{ALT}(\mathrm{U} / \mathrm{L})$ & $14(12 \sim 18.25)$ & $14(10 \sim 17.75)$ & -0.746 & 0.456 \\
\hline $\mathrm{PA}(\mathrm{mg} / \mathrm{L})$ & $123.93(99.39 \sim 151)$ & $93.88(71.97 \sim 123.7)$ & -5.748 & $<0.001^{*}$ \\
\hline ALB $(g / L)$ & $39.76 \pm 4.58$ & $37.58 \pm 5.53$ & 2.809 & $0.006^{*}$ \\
\hline $\mathrm{GLO}(\mathrm{g} / \mathrm{L})$ & $23.1(20.08 \sim 26.78)$ & $22.4(19.3 \sim 25.95)$ & -1.594 & 0.111 \\
\hline $\mathrm{TC}(\mathrm{mmol} / \mathrm{L})$ & $4.4(3.77 \sim 5.06)$ & $4.14(3.67 \sim 5.24)$ & -0.267 & 0.789 \\
\hline $\mathrm{HDL}(\mathrm{mmol} / \mathrm{L})$ & $1.15(0.96 \sim 1.44)$ & $1.13(0.94 \sim 1.36)$ & -0.769 & 0.442 \\
\hline LDL (mmol/L) & $2.51(2.06 \sim 2.99)$ & $2.54(1.94 \sim 3.11)$ & -0.594 & 0.553 \\
\hline $\mathrm{TG}(\mathrm{mmol} / \mathrm{L})$ & $0.97(0.69 \sim 1.31)$ & $1.34(0.91 \sim 2.19)$ & -3.724 & $<0.001^{*}$ \\
\hline HbA1c (\%) & $11.42 \pm 2.49$ & $12.62 \pm 2.15$ & -3.593 & $<0.001^{*}$ \\
\hline C-p (ng/ml) & $0.19(0.09 \sim 0.46)$ & $0.19(0 \sim 0.34)$ & -1.294 & 0.196 \\
\hline
\end{tabular}

Abbreviations: $\beta-H B$ beta-hydroxybutyric acid, $A L B$ albumin, GLO globulin, HbA1c glycosylated hemoglobin, $H D L$ high density lipoprotein, $L D L$ low density lipoprotein, OSM osmolarity, $A G$ anion gap, $P A$ prealbumin, $P G$ plasma glucose, $T C$ total cholesterol, $T G$ triglyceride, WBC white blood cell count, $B M I$ body mass index, BUN serum urea nitrogen, $\mathrm{Cr}$ creatinine, $A L T$ alanine aminotransferase, $C$ - $p$ C-peptide ${ }^{*} P<0.05$ ESS vs. euthyroidism 
Correlating and independent influencing factors of FT3 FT3 levels positively correlated with levels of serum corrected $\mathrm{Na}^{+}, \mathrm{HCO}_{3}{ }^{-}, \mathrm{PA}, \mathrm{K}^{+}, \mathrm{ALB}, \mathrm{GLO}$, and $\mathrm{HDL}$ but negatively correlated with WBC, PG, $\beta-\mathrm{HB}, \mathrm{AG}, \mathrm{TG}$, and $\mathrm{HbA1c}$. There was no significant correlation between levels of FT3 and BUN, Cr, $\mathrm{Cl}^{-}$, OSM, ALT, TC, LDL, and C-p $(P>0.05$, data not shown). Variables showing significant correlation were subjected to multivariate linear regression analysis, which showed that $\beta$ $\mathrm{HB}, \mathrm{HCO}_{3}{ }^{-}, \mathrm{AG}, \mathrm{PA}$, and $\mathrm{HbA1c}$ independently affected FT3 levels (Table 2). The correlations between these independent variables and FT3 are shown in the scatter plot on Fig. $1(\mathrm{r}=-0.642,0.681,-0.377,0.581,-0.309$, respectively; $P<0.01)$.

\section{Correlating and independent influencing factors of FT4}

FT4 levels positively correlated with serum levels of corrected $\mathrm{Na}^{+}, \mathrm{HCO}_{3}{ }^{-}, \mathrm{PA}, \mathrm{ALB}, \mathrm{GLO}$, and $\mathrm{HDL}$ but negatively correlated with WBC, $\mathrm{PG}, \beta-\mathrm{HB}, \mathrm{AG}, \mathrm{Cl}^{-}, \mathrm{TG}$, and HbA1c. There was no significant correlation between FT4 levels and BUN, Cr, $\mathrm{K}^{+}$, OSM, ALT, TC, LDL, and C-p $(P>0.05$, data not shown). Variables showing significant correlation were subjected to multivariate linear regression analysis, which showed that $\beta-\mathrm{HB}, \mathrm{HCO}^{-}$, and ALB significantly affected FT4 levels (Table 3 ). The correlations between these variables and FT4 levels are shown in the scatter plot on Fig. $2(r=-0.489,0.338$, 0.529 , respectively; $P<0.01$ ).

\section{Correlating and independent influencing factors of TSH}

TSH showed positive correlation with levels of corrected $\mathrm{Na}{ }^{+}, \mathrm{HCO}_{3}{ }^{-}$, OSM, TC, and LDL but negative correlation with WBC, $\beta-\mathrm{HB}$, and BUN. There was no significant correlation between TSH and levels of PG, $\mathrm{K}^{+}, \mathrm{Cl}^{-}$, Cr, ALT, AG, PA, TG, HbA1c, ALB, GLO, HDL, and C-

Table 2 Correlating factors of FT3 in DKA/DK children

\begin{tabular}{llllll}
\hline Variables & $\mathrm{B}$ & $\mathrm{SD}$ & Beta & $\mathrm{T}$ & $\mathrm{P}$ \\
\hline WBC & -0.016 & 0.011 & -0.092 & -1.417 & 0.159 \\
$\mathrm{PG}$ & -0.001 & 0.01 & -0.007 & -0.122 & 0.903 \\
$\beta$-HB & -0.151 & 0.048 & -0.331 & -3.116 & $0.002^{*}$ \\
Corrected Na $^{+}$ & -0.006 & 0.017 & -0.02 & -0.351 & 0.726 \\
$\mathrm{~K}^{+}$ & -0.013 & 0.102 & -0.008 & -0.128 & 0.898 \\
$\mathrm{HCO}_{3}{ }^{-}$ & 0.067 & 0.019 & 0.342 & 3.603 & $<0.001^{*}$ \\
$\mathrm{AG}$ & 0.042 & 0.02 & 0.197 & 2.161 & $0.033^{*}$ \\
$\mathrm{PA}$ & 0.011 & 0.003 & 0.3 & 3.961 & $<0.001^{*}$ \\
$\mathrm{ALB}$ & 0.02 & 0.02 & 0.076 & 1.04 & 0.3 \\
$\mathrm{GLO}$ & -0.013 & 0.016 & -0.049 & -0.815 & 0.417 \\
$\mathrm{HDL}$ & 0.113 & 0.261 & 0.028 & 0.434 & 0.665 \\
$\mathrm{TG}$ & -0.069 & 0.067 & -0.064 & -1.031 & 0.305 \\
$\mathrm{HbA} 1 \mathrm{C}$ & -0.07 & 0.034 & -0.121 & -2.082 & $0.039^{*}$ \\
\hline${ }^{* P}<0.05$ & & & & &
\end{tabular}

${ }^{*} P<0.05$ p $(P>0.05)$, data not shown. Variables which showed significant correlation were subjected to multivariate linear regression analysis, which revealed that only serum HCO3- levels had an independent and significant effect on TSH levels (Table 4). The correlations between serum $\mathrm{HCO}^{-}$and $\mathrm{TSH}$ levels are shown in the scatter plot on Fig. $3(\mathrm{r}=-0.28, P<0.01)$.

\section{Logistic regression of adjudicated thyroid function group with metabolic covariates}

Logistic regression model analysis used the thyroid function subgroup (euthyroid or ESS group) as a nonparametric dependent variable and significantly correlated variables in Table 1 as parametric independent variables. As shown in Table 5, serum $\mathrm{HCO}_{3}{ }^{-}$levels was the only factor independently and significantly associated with thyroid function group adjudication $(\mathrm{OR}=0.845$, $P=0.004,95 \% \mathrm{CI}=0.752-0.949$ ).

\section{Discussion}

The present work focused on the interplay of metabolic disorders and deranged free thyroid hormone levels in DKA/DK pediatric patients with ESS, which few studies have previously elucidated. The results indicated a poorer glycemic control in these patients as evidenced by higher plasma glucose and glycosylated hemoglobin levels. They also showed a higher degree of acidosis, indicated by higher levels of anion gap and $\beta-\mathrm{HB}$, as well as a lower level of bicarbonate. Moreover, serum albumin and pre-albumin were reduced in ESS pediatric patients.

Abnormal serum thyroid hormone levels have been well described in patients admitted with acute critical illness $[18,20-22]$. The exact underlying causes have not yet been clarified although many hypothesis have been proposed [12, 18, 23, 24]. In previous research, FT3 and FT4 levels were positively correlated with bicarbonate levels and negatively correlated with $\mathrm{HbA1c}$ and AG levels [13]. In the present study, we evaluated the role of more parameters including acute phase reactants and metabolic parameters in the specific situation. Linear regression analysis confirmed that $\beta-\mathrm{HB}$ and $\mathrm{HCO}_{3}{ }^{-}$levels had an independent influence on both FT4 and FT3 levels while serum pre-albumin and albumin levels related to FT3 alone and FT4 alone, respectively. In addition, $\mathrm{HCO}_{3}{ }^{-}$was demonstrated as the only significantly independent influencing factor on TSH.

Previous studies have noticed the relationship between acidosis and free thyroid hormones levels [23, 25]. Indeed, lower T4 and T3 and higher reverse T3 (rT3) serum concentrations were found in patients with metabolic acidosis [25]. Rashidi et al. reported that the lower the $\mathrm{pH}$ in DKA patients, the lower the FT3 levels [26]. $\mathrm{pH}$ may be the most important factor directly or 

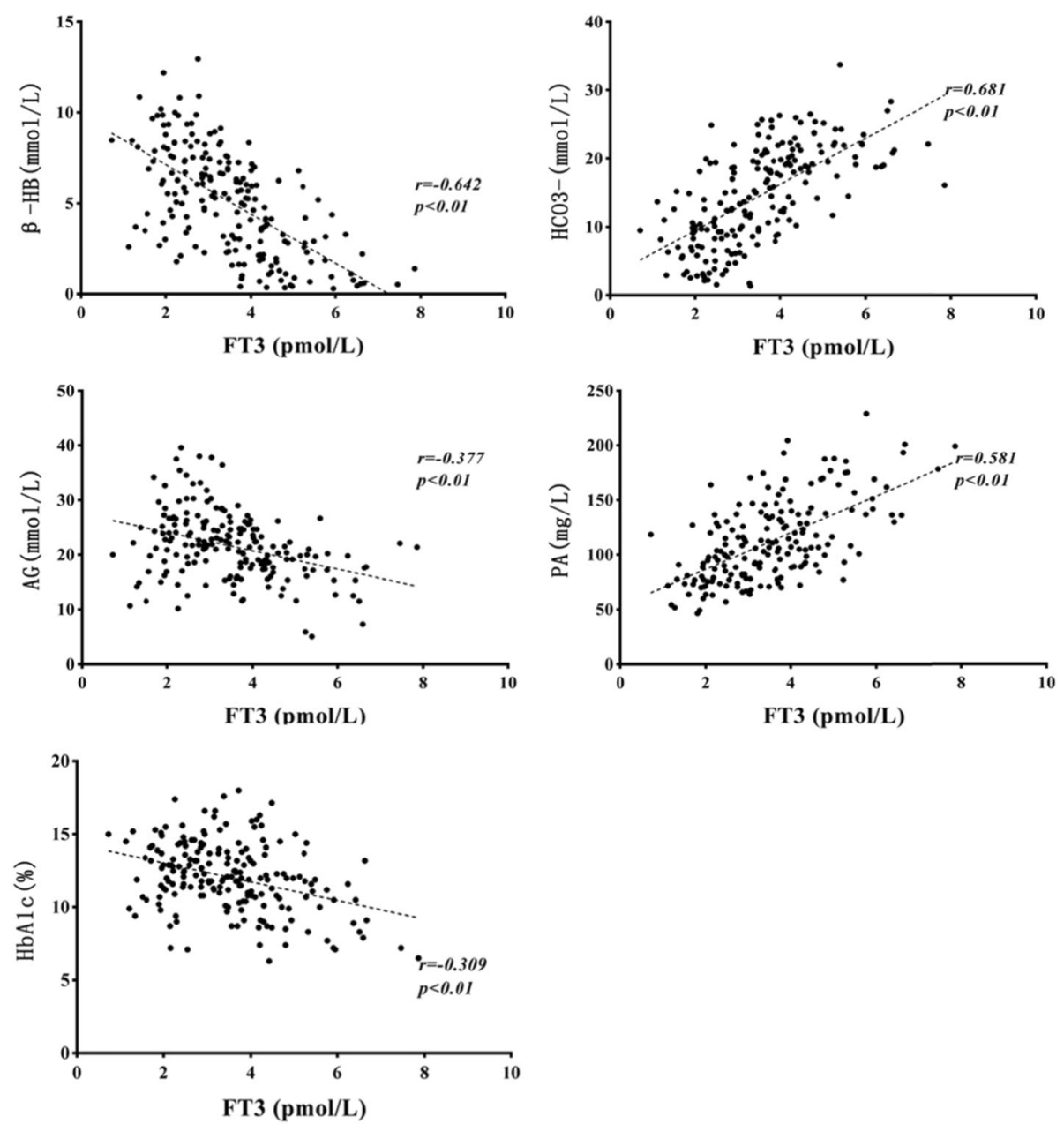

Fig. 1 Correlations between $\mathrm{FT} 3$ and $\beta-\mathrm{HB}, \mathrm{HCO}_{3}{ }^{-}, \mathrm{AG}, \mathrm{PA}, \mathrm{HbA1c}$. Abbreviations: $\beta-\mathrm{HB}$, beta-hydroxybutyric acid; $\mathrm{AG}$, anion gap; PA, prealbumin aminotransferase; $\mathrm{HbA} 1 \mathrm{c}$, glycosylated hemoglobin

Table 3 Correlating factors of FT4 in DKA/DK children

\begin{tabular}{llllll}
\hline Variables & $\mathrm{B}$ & $\mathrm{SD}$ & Beta & $\mathrm{T}$ & $\mathrm{P}$ \\
\hline $\mathrm{WBC}$ & -0.009 & 0.045 & -0.017 & -0.199 & 0.843 \\
$\mathrm{PG}$ & -0.003 & 0.039 & 0.007 & 0.086 & 0.931 \\
$\beta-\mathrm{HB}$ & -0.434 & 0.196 & -0.303 & -2.216 & $0.028^{*}$ \\
Corrected Na $^{+}$ & 0.095 & 0.077 & 0.103 & 1.237 & 0.218 \\
$\mathrm{HCO}_{3}{ }^{-}$ & 0.156 & 0.084 & 0.253 & 1.849 & $0.047^{*}$ \\
$\mathrm{AG}$ & 0.07 & 0.082 & 0.103 & 0.848 & 0.398 \\
$\mathrm{PA}$ & 0.013 & 0.011 & 0.119 & 1.219 & 0.225 \\
$\mathrm{TG}$ & 0.135 & 0.27 & 0.04 & 0.501 & 0.617 \\
$\mathrm{HbA} 1 \mathrm{C}$ & 0.036 & 0.136 & 0.02 & 0.268 & 0.789 \\
$\mathrm{Cl}{ }^{-}$ & -0.07 & 0.039 & -0.158 & -1.782 & 0.077 \\
$\mathrm{ALB}$ & 0.164 & 0.078 & 0.193 & 2.093 & $0.038^{*}$ \\
$\mathrm{GLO}$ & -0.026 & 0.064 & -0.032 & -0.413 & 0.681 \\
$\mathrm{HDL}$ & 1.338 & 1.053 & 0.107 & 1.271 & 0.206 \\
\hline${ }^{* P}<0.05$ & & & & &
\end{tabular}

indirectly affecting iodo-thyronine metabolism and regulation in vitro and in vivo [25]. Our results were consistent with these studies as we also found metabolic acidosis (reflected by serum bicarbonate levels) being the most important factor correlated with parameters of thyroid function tests (i.e. FT3, FT4, and TSH). However, we still could not determine from our data whether ESS is a direct effect of $\mathrm{pH}$ or a more general effect of severity of DKA illness.

Many studies have suggested that blood $\beta-\mathrm{HB}$ can be used to rapidly and accurately diagnose DK/DKA in hyperglycemic patients [27, 28]. Measurement of blood ketones has been recommended in national guidelines in UK for assessment of response to therapy and in tailoring insulin infusion rates [29]. However, few studies have detected the relationship between $\beta-\mathrm{HB}$ and thyroid function. Boado et al. found that $\beta-\mathrm{HB}$ may induce a moderate depression of pituitary and plasma TSH in rats [30]. Our study showed a strong negative correlation 

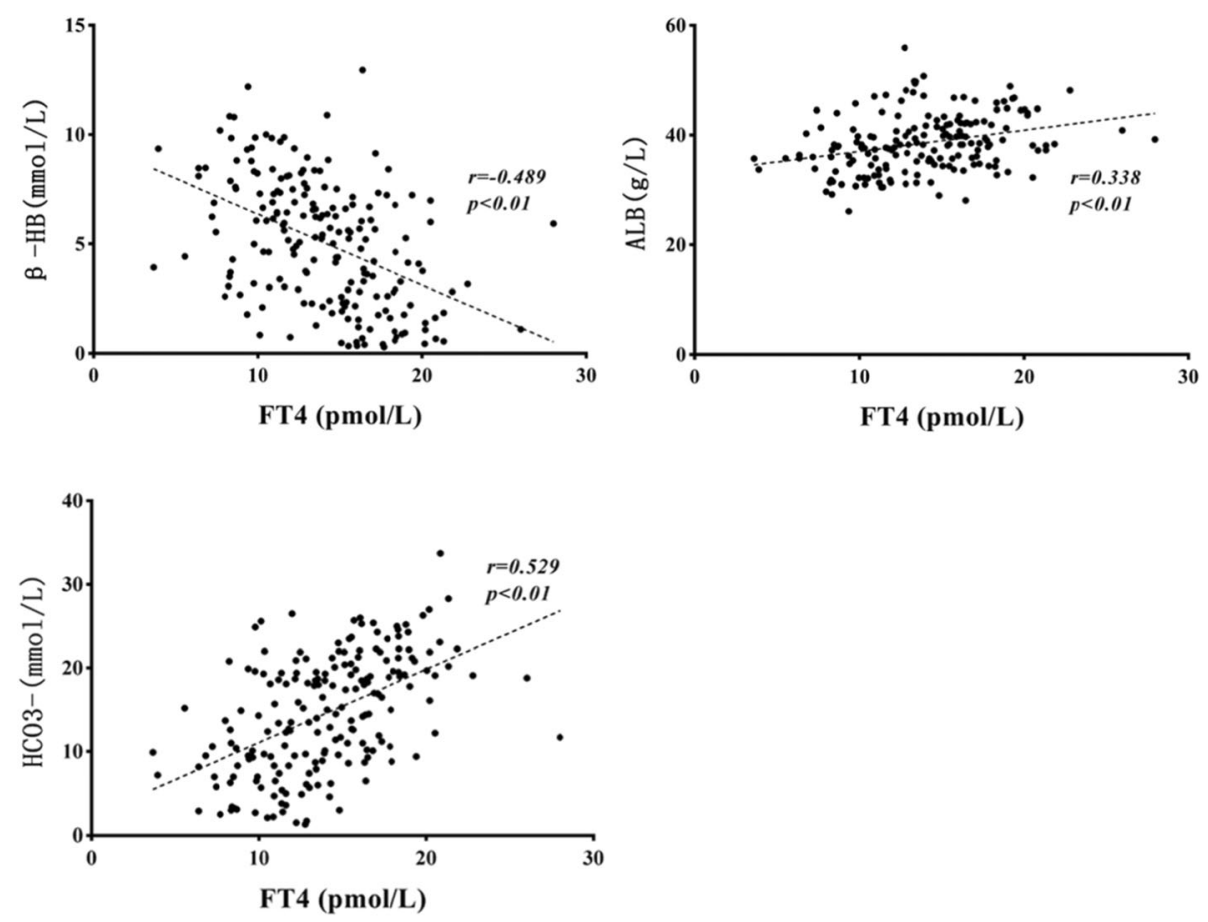

Fig. 2 The correlations between $\mathrm{FT} 4$ and $\beta-\mathrm{HB}_{3} \mathrm{HCO}_{3}{ }^{-}, \mathrm{ALB}$. Abbreviation: ALB, albumin

between levels of $\beta-\mathrm{HB}$ and free thyroid hormone concentrations which may also be the consequence of TSH decline.

As for the underlying reasons for the low serum albumin or pre-albumin in DK/DKA patients with ESS, malnutrition might not be a key factor as there was no significant difference in BMI between ESS and euthyroidism groups in this study. Albumin synthesis in hepatocytes depends on sufficient insulin secretion [31]. It has been demonstrated that insulin deficiency reduces liver albumin production while insulin infusion in diabetic patients enhances live albumin synthesis [32]. In the case of children with longstanding diabetes, the worse compliance and the lower insulin infusion dosing are more likely occurring with ESS. Therefore, in the

Table 4 Correlating factors of TSH in DKA/DK children

\begin{tabular}{llllll}
\hline Variables & B & SD & Beta & $T$ & $P$ \\
\hline WBC & -0.009 & 0.018 & -0.05 & -0.495 & 0.621 \\
$\beta-H B$ & 0.037 & 0.059 & 0.08 & 0.632 & 0.529 \\
${\text { corrected } \mathrm{Na}^{+}}^{+}$ & 0.016 & 0.028 & 0.052 & 0.563 & 0.575 \\
$\mathrm{HCO}_{3}{ }^{-}$ & 0.071 & 0.025 & 0.362 & 2.834 & $0.005^{*}$ \\
$\mathrm{BUN}^{*}$ & -0.025 & 0.052 & -0.042 & -0.493 & 0.623 \\
OSM & 0.005 & 0.005 & 0.079 & 0.876 & 0.383 \\
TC & 0.134 & 0.262 & 0.101 & 0.511 & 0.61 \\
$L D L$ & 0.1 & 0.35 & 0.058 & 0.284 & 0.777 \\
\hline${ }^{*} P<0.05$ & & & & &
\end{tabular}

present study, the more absolute lack of insulin could partly account for the lower level of serum albumin and pre-albumin in T1DM patients with DKA/DK. Moreover, albumin deficiency occurs when DKA/DK pediatric patients are critical ill, and reduced albumin in ESS might indicate a more serious condition.

In the present study, children in the ESS group had higher WBC levels, which were negatively correlated with levels of FT3, FT4, and TSH. Elevated WBC has also been shown to be significantly correlated with severity of DKA and DK in other studies [33, 34]. This

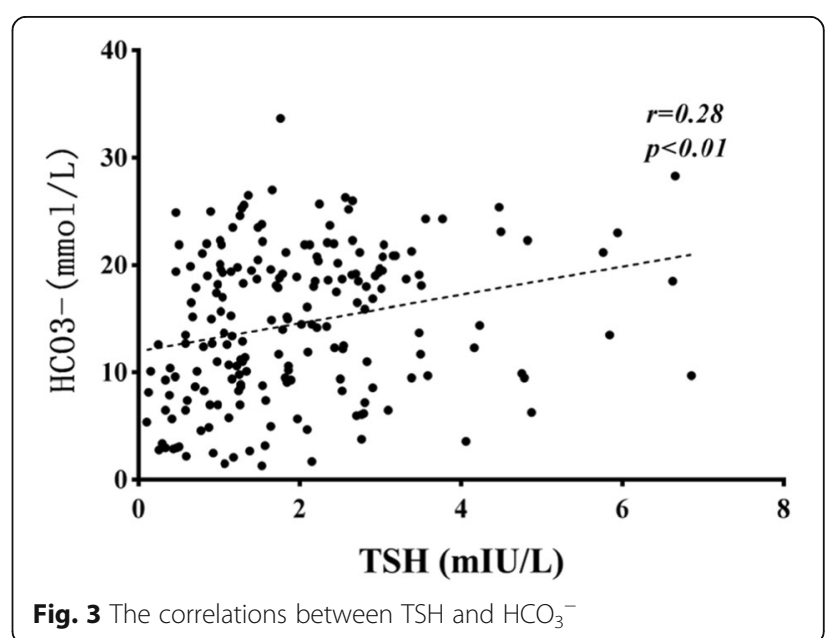


Table $\mathbf{5}$ Logistic regression on the predictors of deranged thyroid function in DKA/DK patients

\begin{tabular}{|c|c|c|c|c|c|c|c|}
\hline \multirow[t]{2}{*}{ Variables } & \multirow[t]{2}{*}{ B } & \multirow[t]{2}{*}{$\boldsymbol{p}$-value } & \multirow[t]{2}{*}{ Wald } & \multirow{2}{*}{$\begin{array}{l}\text { Adjusted } \\
\text { p-value }\end{array}$} & \multirow[t]{2}{*}{ OR } & \multicolumn{2}{|c|}{$95 \%$ C.I. for OR } \\
\hline & & & & & & Inferior & Superior \\
\hline$\overline{W B C}$ & 0.127 & 0.062 & 4.227 & 0.050 & 1.136 & 1.006 & 1.283 \\
\hline$P G$ & 0 & 0.028 & 0 & 0.996 & 1 & 0.946 & 1.057 \\
\hline$\beta-H B$ & 0.14 & 0.145 & 0.937 & 0.333 & 1.15 & 0.866 & 1.558 \\
\hline $\mathrm{HCO}^{-}$ & -0.168 & 0.059 & 8.072 & $0.004^{*}$ & 0.845 & 0.752 & 0.949 \\
\hline$A G$ & -0.02 & 0.066 & 0.097 & 0.756 & 0.98 & 0.862 & 1.114 \\
\hline PA & -0.005 & 0.008 & 0.436 & 0.509 & 0.995 & 0.979 & 1.011 \\
\hline TG & 0.227 & 0.267 & 0.723 & 0.395 & 1.255 & 0.743 & 2.119 \\
\hline $\mathrm{HbA1c}$ & 0.179 & 0.115 & 2.401 & 0.121 & 1.196 & 0.954 & 1.499 \\
\hline ALB & -0.071 & 0.057 & 1.591 & 0.207 & 0.931 & 0.833 & 1.04 \\
\hline
\end{tabular}

phenomenon is most likely a leukemoid-like reaction instead of a systemic inflammatory response, as no evidence for fever or bacteria or virus infection was present. Also, in both adult and pediatric DKA patients, the response to milieu interne changes including deranged hormones, cytokines, and mediators actuates white blood cell count elevation [35].

We also found lower serum sodium in ESS patients, which when corrected by using blood glucose concentration showed no significant difference between the ESS and euthyroidism groups. So, this could be pseudohyponatremia due to the water being osmotically drawn into the vascular space in hyperglycemia. Although low serum sodium concentration has been shown to be indicative of poor outcome or cerebral edema in DKA, the present study did not reveal its relationship with ESS.

Our study had several drawbacks as it was a retrospective study with a small number of participants. We did not measure rT3 levels which are usually elevated in ESS patients. Moreover, we did not correlate ESS with recovery times and hospital stay duration as well as other parameters associated with DKA such as venous thrombosis and cerebral edema.

In addition, as detection limitations, we did not apply equilibrium dialysis or ultrafiltration methods to measure free thyroid hormones in the serum of patients which might underestimate the concentration of FT3 or FT4. This inaccuracy could lead to overdiagnosis of ESS and misclassification, particularly in marginal cases. Although the setting of euthyroidism control partly compensated for this weakness, the impact of this methodology on the outcome might be inevitable.

\section{Conclusions}

Lower levels of free thyroid hormones were found to be associated with higher degree of acidosis and hence with the severity of DKA/DK.

\section{Abbreviations}

B-HB: beta-hydroxybutyric acid; ALB: Albumin; DK: Diabetic ketosis; DKA: Diabetic ketoacidosis; ESS: Euthyroid sick syndrome; GLO: Globulin; HbA1c: glycosylated hemoglobin; HDL: High density lipoprotein; LDL: Low density lipoprotein; OSM: Osmolarity; PA: Prealbumin; PG: Plasma glucose; TC: Total cholesterol; TG: Triglyceride; WBC: White blood cell count

\section{Acknowledgments}

The authors thank the staff of the Department of Pediatrics, Shandong Provincial Hospital Affiliated to Shandong University for their cooperation and their permission to conduct this study.

\section{Authors' contributions}

PS collected and analyzed the data, drafted the initial manuscript and reviewed the manuscript. GL conceptualized and designed the study, and supervised the conduct of the study. SG helped to collect and analyze the data, Daogang Qin, Sen Li and Ying Luan critically edited the manuscript. All authors gave their final approval for the version to be published.

Funding

There is no funding source.

Availability of data and materials

The datasets are available from the corresponding author on reasonable request.

Ethics approval and consent to participate

Ethical approval was obtained from the Ethical Committee of Shandong Provincial Hospital. All patients and parents gave their written informed consent after full explanation of the purpose and nature of all procedures used.

Consent for publication

Not applicable.

\section{Competing interests}

The authors declare that they have no competing interests.

\section{Author details}

${ }^{1}$ Department of Pediatrics, Shandong Provincial Hospital, Cheeloo College of Medicine, Shandong University, Jinan 250021, Shandong, China. ${ }^{2}$ Department of Pediatrics, Liaocheng People's Hospital, Liaocheng 252000, Shandong, China. ${ }^{3}$ Department of Endocrinology, Liaocheng People's Hospital, Liaocheng 252000, Shandong, China.

Received: 1 April 2020 Accepted: 25 August 2020

Published online: 01 September 2020

\section{References}

1. Weng J, Zhou Z, Guo L, Zhu D, Ji L, Luo X, Mu Y, Jia W. Incidence of type 1 diabetes in China, 2010-13: population based study. Bmj. 2018:360:5295. https://doi.org/10.1136/bmj.j5295.

2. CDC. National Diabetes Statistics Report. Centers for disease control and preventoin. Atlanta: U.S. Dept of Health and Human Services; 2017.

3. Rodacki M, Pereira JR, Nabuco de Oliveira AM, Barone B, Mac Dowell R, Perricelli P, Bravo MT, de Oliveira MM, Brum JD, Belem LC, de Ornellas PG, Berardo RS, Luescher J, Campos L, Vangelotti Ade M, Kupfer R, Zajdenverg L, Milech A, Paulo de Oliveira JE. Ethnicity and young age influence the frequency of diabetic ketoacidosis at the onset of type 1 diabetes. Diabetes Res Clin Pract. 2007;78(2):259-62. https://doi.org/10. 1016/j.diabres.2007.04.002

4. Meuwese CL, Carrero JJ, Cabezas-Rodríguez I, Heimburger O, Barany P, Lindholm B, Qureshi AR, Ripsweden J, Dekker FW, Stenvinkel P. Nonthyroidal illness: a risk factor for coronary calcification and arterial stiffness in patients undergoing peritoneal dialysis? J Intern Med. 2013; 274(6):584-93. https://doi.org/10.1111/joim.12107.

5. Girvent M, Maestro S, Hernández R, Carajol I, Monné J, Sancho JJ, Gubern $J M$, Sitges-Serra A. Euthyroid sick syndrome, associated endocrine abnormalities, and outcome in elderly patients undergoing emergency operation. Surgery. 1998;123(5):560-7. 
6. Yildizdaş D, Onenli-Mungan N, Yapicioğlu H, Topaloğlu AK, Sertdemir Y, Yüksel B. Thyroid hormone levels and their relationship to survival in children with bacterial sepsis and septic shock. J Pediatr Endocrinol Metab. 2004;17(10):1435-42.

7. Su W, Zhao XQ, Wang M, Chen H, Li HW. Low T3 syndrome improves risk prediction of in-hospital cardiovascular death in patients with acute myocardial infarction. J Cardiol. 2018;72(3):215-9. https://doi.org/10.1016/j. jjcc.2018.02.013.

8. Wang YF, Heng JF, Yan J, Dong L. Relationship between disease severity and thyroid function in Chinese patients with euthyroid sick syndrome. Medicine (Baltimore). 2018;97(31):e11756. https://doi.org/10.1097/MD. 0000000000011756.

9. Ogbonna SU, Ezeani IU, Okafor Cl, Chinenye S. Association between glycemic status and thyroid dysfunction in patients with type 2 diabetes mellitus. Diabetes Metab Syndr Obes. 2019;12:1113-22. https://doi.org/10. 2147/DMSO.S204836.

10. Tahirović H, Dućić V, Smajić A. Euthyroid sick syndrome in type I diabetes mellitus in children and adolescents. Acta paediatrica Hungarica. 1991;31(1): 67-73.

11. Joseph J, Saroha V, Payne H, Paul P, Didi M, Isherwood D, Blair J. Thyroid function at diagnosis of type I diabetes. Arch Dis Child. 2011;96(8):777-9. https://doi.org/10.1136/adc.2009.168799

12. Warner $\mathrm{MH}$, Beckett $\mathrm{GJ}$. Mechanisms behind the non-thyroidal illness syndrome: an update. J Endocrinol. 2010;205(1):1-13. https://doi.org/10. 1677/joe-09-0412.

13. Hu YY, Li GM, Wang W. Euthyroid sick syndrome in children with diabetic ketoacidosis. Saudi Med J. 2015;36(2):243-7. https://doi.org/10.15537/smj. 2015.2.10304.

14. American Diabetes A. Diagnosis and classification of diabetes mellitus. Diabetes Care. 2014;37(Suppl 1):S81-90. https://doi.org/10.2337/dc14-S081.

15. Mayer-Davis EJ, Kahkoska AR, Jefferies C, Dabelea D, Balde N, Gong CX, Aschner P, Craig ME. ISPAD clinical practice consensus guidelines 2018: definition, epidemiology, and classification of diabetes in children and adolescents. Pediatr Diabetes. 2018;19:7-19. https://doi.org/10.1111/pedi. 12773.

16. Basetty S, Yeshvanth Kumar GS, Shalini M, Angeline RP, David KV, Abraham S. Management of diabetic ketosis and ketoacidosis with intramuscular regular insulin in a low-resource family medicine setting. J Family Med Prim Care. 2017;6(1):25-8. https://doi.org/10.4103/2249-4863.214992.

17. Vale C, Neves JS, von Hafe M, Borges-Canha M, Leite-Moreira A. The role of thyroid hormones in heart failure. Cardiovasc Drugs Ther. 2019;33(2):179-88. https://doi.org/10.1007/s10557-019-06870-4.

18. Lee S, Farwell AP. Euthyroid sick syndrome. Compr Physiol. 2016;6(2):107180. https://doi.org/10.1002/cphy.c150017.

19. Hursh BE, Ronsley R, Islam N, Mammen C, Panagiotopoulos C. Acute kidney injury in children with type 1 Diabetes hospitalized for diabetic ketoacidosis. JAMA Pediatr. 2017;171(5):e170020. https://doi.org/10.1001/jamapediatrics. 2017.0020

20. Fliers $E$, Bianco $A C$, Langouche L, Boelen A. Thyroid function in critically ill patients. Lancet Diabetes Endocrinol. 2015;3(10):816-25. https://doi.org/10. 1016/s2213-8587(15)00225-9.

21. Van den Berghe G. Non-thyroidal illness in the ICU: a syndrome with different faces. Thyroid. 2014;24(10):1456-65. https://doi.org/10.1089/thy. 2014.0201.

22. von Saint Andre-von Arnim A, Farris R, Roberts JS, Yanay O, Brogan TV, Zimmerman JJ. Common endocrine issues in the pediatric intensive care unit. Crit Care Clin. 2013;29(2):335-58. https://doi.org/10.1016/j.ccc.2012.11. 006.

23. Mirboluk AA, Rohani F, Asadi R, Eslamian MR. Thyroid function test in diabetic ketoacidosis. Diabetes Metab Syndr. 2017;11(Suppl 2):S623-5. https://doi.org/10.1016/.dsx.2017.04.015.

24. Maiden MJ, Torpy DJ. Thyroid hormones in critical illness. Crit Care Clin. 2019;35(2):375-88. https://doi.org/10.1016/j.ccc.2018.11.012

25. Tahirovic HF. Thyroid hormones changes in infants and children with metabolic acidosis. J Endocrinol Investig. 1991;14(9):723-6. https://doi.org/ 10.1007/BF03347903

26. Rashidi H, Ghaderian SB, Latifi SM, Hoseini F. Impact of diabetic ketoacidosis on thyroid function tests in type 1 diabetes mellitus patients. Diabetes Metab Syndr. 2017;11(Suppl 1):S57-9. https://doi.org/10.1016/j.dsx.2016.12. 001
27. Misra S, Oliver NS. Utility of ketone measurement in the prevention, diagnosis and management of diabetic ketoacidosis. Diabetic Med. 2015; 32(1):14-23. https://doi.org/10.1111/dme.12604.

28. Dhatariya K. Blood ketones: measurement, interpretation, limitations, and utility in the Management of Diabetic Ketoacidosis. Rev Diabet Stud. 2016 13(4):217-25. https://doi.org/10.1900/RDS.2016.13.217.

29. Dhatariya KK, Umpierrez GE. Guidelines for management of diabetic ketoacidosis: time to revise? Lancet Diabetes Endocrinol. 2017;5(5):321-3. https://doi.org/10.1016/\$2213-8587(17)30093-1.

30. Boado R, Colombo O, Zaninovich AA. Effects of diabetes, betahydroxybutyric acid and metabolic acidosis on the pituitary-thyroid axis in the rat. J Endocrinol Investig. 1985;8(2):107-11. https://doi.org/10.1007/ bf03350658.

31. Cheng P-C, Hsu S-R, Cheng Y-C. Association between serum albumin concentration and ketosis risk in hospitalized individuals with type 2 Diabetes mellitus. J Diabetes Res. 2016;2016:1-5. https://doi.org/10.1155/ 2016/1269706.

32. De Feo P, Gaisano MG, Haymond MW. Differential effects of insulin deficiency on albumin and fibrinogen synthesis in humans. J Clin Invest. 1991;88(3):833-40.

33. Xu W, Wu HF, Ma SG, Bai F, Hu W, Jin Y, Liu H. Correlation between peripheral white blood cell counts and hyperglycemic emergencies. Int J Med Sci. 2013;10(6):758-65. https://doi.org/10.7150/ijms.6155.

34. Karavanaki K, Kakleas K, Georga S, Bartzeliotou A, Mavropoulos G, Tsouvalas M, Vogiatzi A, Papassotiriou I, Karayianni C. Plasma high sensitivity C-reactive protein and its relationship with cytokine levels in children with newly diagnosed type 1 diabetes and ketoacidosis. Clin Biochem. 2012;45(16-17): 1383-8. https://doi.org/10.1016/..clinbiochem.2012.05.003.

35. Gonzalez LK, Malhotra S, Levine M, Jacobson-Dickman E. Leukemoid reaction in a pediatric patient with diabetic ketoacidosis. Pediatr Emerg Care. 2017;33(8):e27-9. https://doi.org/10.1097/PEC.0000000000000558.

\section{Publisher's Note}

Springer Nature remains neutral with regard to jurisdictional claims in published maps and institutional affiliations.
Ready to submit your research? Choose BMC and benefit from:

- fast, convenient online submission

- thorough peer review by experienced researchers in your field

- rapid publication on acceptance

- support for research data, including large and complex data types

- gold Open Access which fosters wider collaboration and increased citations

- maximum visibility for your research: over $100 \mathrm{M}$ website views per year

At BMC, research is always in progress.

Learn more biomedcentral.com/submissions 